\title{
The Effect of Attachment Style on Adolescent's Conflict Resolution Styles
}

\author{
Zaimah Dwita Arum Primasari Sutiyo \\ University of Muhammadiyah Malang \\ sutiyozaimah@gmail.com
}

\begin{abstract}
Attach figure (nanny or mother) is a thing that not spared in individual parenting from infants to adults. Parenting provided can affect the psychological development of the individual in the future and help individuals to explore their social life, including when they facing the daily conflict. The purpose of this research is to determine the effect of attachment style to conflict resolution's style used by adolescent. The design used quantitative correlational research with method of multiple regression, the number of subjects is 185 adolescent. The measurements using instrumentsof Rahim Organizational Conflict Inventory-II (ROCI-II) and The Attachment Style Questionnaire (ASQ). The results showed there is significant positive correlation between attachment style with collaborating, accommodating dan compromising styles. While competing style have no significant correlation with attachment style.
\end{abstract}

Keywords: Attachment style, conflict resolution styles, adolescent.

\section{INTRODUCTION}

The family is the smallest unit of society that is closest to the adolescents and has the first responsibility to maintaining the growth and development of the individual from the baby to becoming an adult. At this stage of development, the invidual grows to form a personality and behavioral pattern that will largely be settled in adulthood. This development greatly affects the interaction of adolescents with their environment, such as interaction with peers. Social interaction that occurs can develop with the ability of human beings able to develop the nature of openness and trust with the environment. It will lead to the establishment or opening of conflicts in adolescents. Conflicts can happen because of the lack of common goals and interpersonal understanding, the emergence of a third party in a new relationship, a change in the nature of the relationship causing the problem, and the presence of expectations in the individual which inconsistent with the other individual (Hadipranoto, 2012). But on the other hand, peers as other individuals who have similar experiences, will be a place for adolescentss to find solutions, to be a place of dependence and mutual help each other.

Surveys and research conducted in 2012 by the Department of Communications Science and Community Development, Faculty of Human Ecology, Institute of Agricultural Bogor (IPB) said students engaged themselves in the action of brawl as a form of solidarity from within themselves. Angga Tamimi Usman, a researcher from IPB, said that $62.5 \%$ of students were involved in fighting due to solidarity or loyalty, $25 \%$ considered brawl as routine or fraudulent, $7.5 \%$ due to grudge and $2.5 \%$ based on personal problems (Prima, 2012). Based on the phenomenon has occurred, adolescents should be able to create appropriate conflict resolution and in accordance with the problems itself. Each individual relative uses different ways of solving problems with other individuals. Constructive conflict resolution can help adolescents to grow into individuals with good behavior and emotional control, and adolescents are trained to think critically and creatively in problems solving. It can also be a reference for adolescentss when it comes to confronting the same or more severe conflicts later. Thus the conflicts faced by adolescentss not only have a negative impact on its development but also have a positive impact.

A studied by Havengan (2008) suggests a significant relationship, though not overwhelming, that gender and age can influence individuals in using conflict resolution styles, which female more often use relationship styles than male, as well as younger children who use dominating/ competing style more often than older generation. This study was reinforced by the resulted of Vokić \& Sontor (2010) whom described that individual characteristics also affected the conflict resolution style, i.e. female who more often uses accomodating and compromising style than male. This is allegedly because female are born with higher concerns of paying attention to others than themselves so as she enable them to give in to the other side.

Conflict resolution skills are personal resources that evolve over time. These skills can't be provided by others, but parents, educators and caregivers/ nanny can support developments with modeling skill and aware of the process of develompent of conflict resolution characteristics in children. Conflict resolution skills that begin to develop from early interaction of childrens with others can stimulated individual development, 
reconstructs conflict situations, and gained new strategies for dealing with stress (Broadbear \& Broadbear, 2000). Interaction in the social relationships of parents and children was a major sources of emotional and cognitive development in individuals. This relationship refers to a strong emotional bond, especially between the individual and the attach figure or the person who has strong feelings for each other and does many things together to continue the relationship. This relationship be able to give individuals the opportunity to live and explore the wider social life such as peers, spouses and other community environments (Bartholomew and Horowitz, 1991).

If individual gets the maltreatment, especially the one that threatens his welfare, it will also affected the physical, social and emotional development. The researched by Zaenali, Sharifi, Enayati, Asgari and Pasha (2011) showed that authoritarian and neglectful parenting will result in insecure attachment. This form of attachment has a positive correlation with low self-regulation, which in turn increases the susceptibility of drug abuse to children.

The results studied by Collins (2004) stated that individuals with insecure attachments received a message of low-support and judged the message more negatively. Behavioral interactions with their partners were less supportive and significantly worse in the face of stress than individuals with secure attachment. Individuals with insecure attachment feel a low social message as a disadvantage. Otherwise, if adolescents grow with insecure attachment, they tend to develop negative self-schemes and don't believe in their abilities, which then interfere their daily activities, especially in resolving conflicts. Therefore, researchers want to do research to determine the dynamics between the attachment style in adolescents with conflict resolution style they used.

\section{Conflict Resolution}

Conflict resolution is a way of ending disputes between two or more parties involved in a dispute or argument. This is achieved when the mediator acts as a facilitator to ensure that both sides settle their differences peacefully to ensure peace. Tschannen-Moran explains the process of conflict resolution as an integral process in creating programs that can disseminate ideas and skills to avoid, monitor and resolve conflict peacefully (Oredeina \& Eigbe, 2014). Thus it can be concluded that conflict resolution is the process of solving a problem involving individuals and groups.

There are several models of conflict resolution. This model is developed with the idea that there are aspects that become the focus of attention when the individual seeks the goal, namely: concern to self and others. Concern to self measured by the degree of assertiveness or aggressiveness of a person.
Concern to others emphasized by the high level of cooperation.

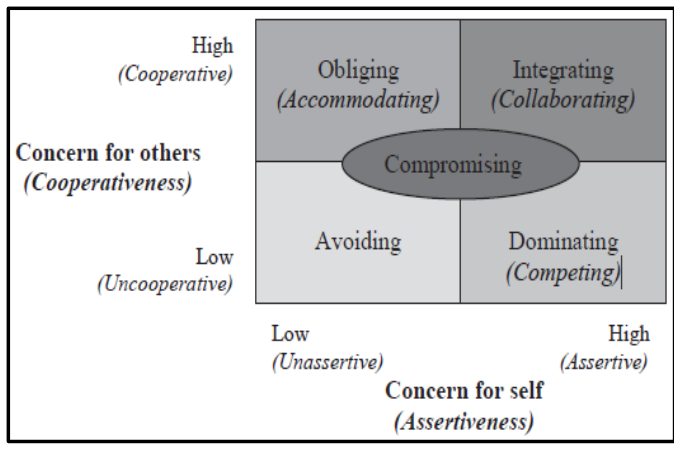

Figure 1. The 2D model of the conflict resolution style

This conflict resolution model identified 5 conflict resolution styles: collaborating style, accommodation style, competing style, avoiding style and compromising style. The collaborating style shows individuals who have a high concern for themselves and others, have a firm and cooperative personality, and are collaborative between the parties. Individuals who are open, have the ability to exchange information, are able to test the differences between parties in the conflict in order to achieve a mutual solution so as to generate a win-win outcome.Individuals with an accommodation style have a high concern for others but are low on self, assertive and cooperative personality. They use self-sacrificing models, willing to sacrifice self-interest to meet the needs of others, willing to place their opponent's interests above themselves, have an attitude to accommodate and accept the opponent's desire, so this style will result in a lose-win outcome (Rahim \& Magner, 1995 ; Vokić \& Sontor, 2010).

The competing style described individual with a high concern for self and others, has a firm personality but not cooperative. They have an aggressive drive to maximize one's profit or satisfy their interests even at the expense of others, regardless of the impact that the other side of the conflict will received. They will maintain a position that he/she believe is right or even just because he/she want to win, so they have a win-win outcome. Individuals with avoiding styles have a low concern for themselves and others, unruly and uncooperative personality. They tend to generate a lose-lose outcome, a withdrawal behavior that allows individuals to withdraw from conflict situations and allow individuals to take the form of diplomatically avoiding problems, hiding disputes, or delaying problems until a certain time. Meanwhile, the compromising style has a characteristic concern that equal between themselves and others, has a strong and cooperative personality. Individuals who tend to give and 
receive or share a middle solution of conflicts, so they produce no-win / no-lose outcomes (Rahim \& Magner, 1995; Vokić \& Sontor, 2010).

Adolescents who develop with a secure attachment will help them grow to be open individuals, have a positive self-concept and be able to express directly the needs within themselves and communicate well to the people around him. With it, adolescents be able to solved problems by providing solutions or solutions to meet the needs of themselves and the parties involved in the conflict so that all of them get the result of resolution which is equally beneficial for all parties.

\section{Attachment style}

The "attachment" term was first proposed by a psychologist from England in 1958 named John Bowlby, that attachment is a strong emotional bond between the baby and the caregiver. Attachment refers to a relationship between two people who have strong feelings for each other and do many things together to continue that relationship. Bwolby believes that the ability of emotional regulation relates to the force of individual attachment and emotional distress thats grow and suitable with the individual attachment style (Iriana \& Ninawati, 2005). The attachment that form in adolescence can't be released directly with the attachment that formed during infancy. Attachment contributed to human life-span development through the emotional support that formed between individuals and their attach figures. Adolescents also can't escape from family bond as they learn to develop another relationships out there (Dewi \& Valentina, 2013).

Secure attachment provide a situation with no problem in caregivers attention and presence as an exploration center. Secure attachment will form when the child gets a warm, consistent and responsive treatment from the caregiver. A secure individual are they whose have low levels of anxiety and avoidance. He/she grow with the belief that they are loved and appreciated by others. Adolescents was able to develop direct and open communication. Meanwhile, adolescent who grow with insecurite attachment will remember bad memories in childhood and show reluctance to explore the environment (Collin \& Feeney, 2004; Santrock, 2002).

Each individual grows up with the ability to use a variety styles of conflict resolution, which some individuals tend to rely on a particular style that suits him/her while there are some other individuals who are not flexible enough to choose the best style to deal with conflict situations (Vokić $\&$ Sontor, 2010). Adolescents who grow up with secure attachment styles have a higher level of emotional intelligence than those with insecure attachment styles (Bonab \& Koohsar, 2011). Adolescents with high emotional intelligence are able to confront and change their stressful conditions into something they can deal with and they are also more sensitive to the surrounding environment. They have effective controls in solving the conflicts. Based on the explanation then made the frame of thought as follows:

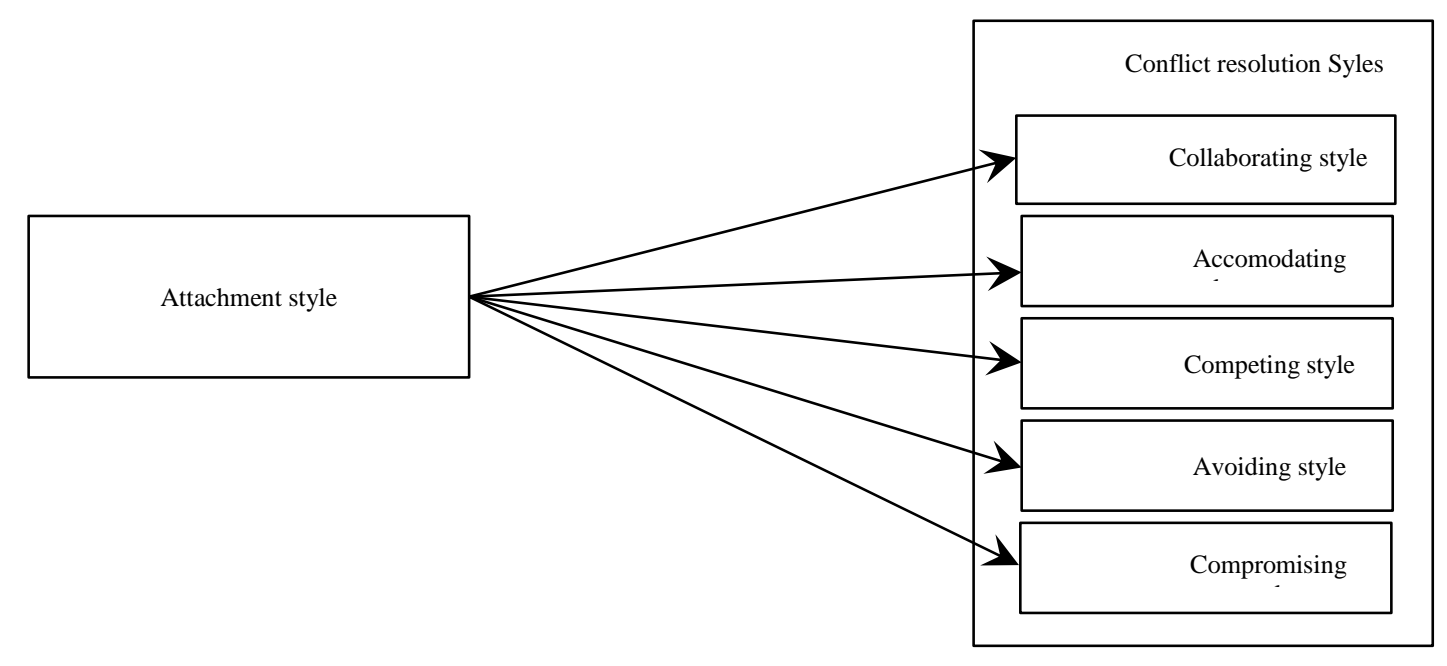

\footnotetext{
Hypothesis

There are five hypotheses were proposed in this study:

H1: There is a positive relationship between attachment style and collaborating style.

$\mathrm{H} 2$ : There is a positive relationship between attachment style and accommodating style.

$\mathrm{H} 3$ : There is a positive relationship between attachment style and dominating style.

$\mathrm{H} 4$ : There is a positive relationship between attachment style and avoiding style.
} 
H5: There is a positive relationship between attachment style and compromising style.

\section{Design}

\section{METHODS}

This research is correlational quantitative research method with multiple regression analysis, that is doing calculation to know whether or not the effect between attachment style and conflict resolution style in adolescents and to know how the relationship between the two valiabel.

\section{Subjects}

Characteristics of subjects in this studied were adolescents with age 15-20 years, male and female, 185 people. Sampling technique used Sampling Quota (Non probability sampling).

\section{Variables and Instruments}

This research uses two variables, where conflict resolution style as dependent variable and attachment style as independent variable. Conflict resolution style measured by using the Organizational Conflict Inventory-II (ROCI-II) scale. This instrument measures 5 styles in dealing with conflicts: compromising, dominating, accommodating, avoiding, and collaborating. Its consists of 28 items using the Likert scale 1-5, from strongly disagree to strongly agree. ROCI-II has a Cronbach's alpha coefficient of 0.72-0.77 and the validity of the extract is 0.40 (Rahim, 1983).

Meanwhile the attachment style was measured by The Attachment Style Questionnaire (ASQ). The instrument consists of 24 items consisting of 4 sub-scales namely secure, fearful, preoccupied and dismissing, using a Likert scale of 1-5, from strongly disagreeing to strongly agreeing. ASQ has adequate internal consistency, with Cronbach's alpha coefficient of 0.73-0.80 (Van Oudenhoven, Hofstra, and Bakker, 2003).

\section{RESULT}

The results of the study discussed about the effect of attachment style on conflict resolution style owned by adolescent and the presence or absence of relationship created by the two variables of the study. The results are shown in table 1.

Table 1. Description of Subjects

\begin{tabular}{cccc}
\hline & Mean & Std. Deviation & N \\
\hline Collaborating style & 4.2066 & .55283 & 185 \\
Accommodating style & 3.2365 & .52436 & 185 \\
Dominating style & 2.5935 & .75983 & 185 \\
Compromising style & 3.8405 & .52283 & 185 \\
Attachment style & 51.77 & 5.875 & 185 \\
\hline
\end{tabular}

The data in table 1 shows the mean and standard deviations of the conflict resolution style in 185 respondents, the highest being the integration style of each with the values of 4.206 and 0.552. This suggests that adolescents, as research subjects, are more likely to use cooperative ways and exchange information with the parties to the conflict with them. Thus, adolescents are more likely to find alternative solutions to resolve conflicts and meet the needs that can benefit both themselves and the opposing side (Friedman, Tidd, Currall, Tsai, 2000).

Table 2. Multiple Regression Analysis Result of Attachment style to Conflict Resolution Style

\begin{tabular}{|c|c|c|c|c|}
\hline & $\begin{array}{l}\text { Collaborating } \\
\text { style }\end{array}$ & $\begin{array}{l}\text { Accommodating } \\
\text { style }\end{array}$ & $\begin{array}{l}\text { Dominating } \\
\text { style }\end{array}$ & $\begin{array}{l}\text { Compromising } \\
\text { style }\end{array}$ \\
\hline \multicolumn{5}{|c|}{$\begin{array}{l}\text { Attachment } \\
\text { style }\end{array}$} \\
\hline$r$ & $.224 *$ & $.226^{*}$ & -.033 & $.133 *$ \\
\hline $\mathrm{R}^{2}$ & .050 & .051 & .001 & .018 \\
\hline
\end{tabular}

Table 3 shows that the attachment style has a positive relationship direction although the correlation is weak with the collaborating style, which is indicated by the coefficient correlation (r) of 0.224 and the significant level of 0.001 ( $p$
$<0.05)$. While $\mathrm{R} 2$ represents a value of 0.050 which means the attachment gives an effect of $5 \%$ on the collaborating style and the remaining $95 \%$ is influenced by other factors not described in the study (H1 accepted). Attachment style also has a 
positive relationship with the accommodating style but this relationship tends to be weak seen from the coefficient correlation of 0.226 and a significant level of 0.001 . The attachment has an effect on the accommodating style with an effective contribution of $5.1 \%$ (H2 accepted).

Otherwise, the influence of the attachment style to the ominating style has a correlation coefficient value of -0.033 , significance level 0.329 , and the effective contribution of the attachment style to the dominant style is only $0.1 \%$ (H3 is rejected). The correlation value between force and compromise force is 0.133 with a significance level of 0.036 . Although the effective contribution by the attachment force is only $1.8 \%$ affecting the compromise style H5 is accepted. While the researcher can not test the hypothesis $\mathrm{H} 4$ because it can not use the measurement with the style dimension to avoid the conflict resolution style.

\section{DISCUSSION}

Based on the results of multiple regression analysis, it can be explained that the attachment style shows a positive relationship with the collaborating, accommodating and compromising style, although this form of relationship tends to be weak but has a significant level of significance ( $p$ $<0.05$ ). The attachment style with the integration style indicates a positive though weak direction with a significant level of significance $(\mathrm{p}=0.001)$. The attachment style gives effect to the collaborating style of $5 \%$. This shows that adolescents with a high attachment style, referring to secure attachment, grow into a person who believes in himself and others, is open and communicative, and able to handle the anxiety arising from stressful situations for him/her. So when he/she faced with conflict situations, adolescents show a cooperative personality, able to place needs on themselves and others equally, and they are able to work with parties involved in the conflict to achieve a mutually beneficial solution for themselves and the parties.

Furthermore, the attachment style indicates the direction of positive but weak relationship to the accommodating style and this relationship indicates a significance level of 0.001 and gives effect to adolescents in using the accommodating style of $5.1 \%$. It shows that the attach figure in the adolescent is able to have an effect on itself to help and prefer sacrificing oneself to others in situations of conflict encountered. Adolescents make themselves personally able to accommodate the wishes of others and even willing to move to the point of view of others when resolving conflict (Friedman, Tidd, Currall, Tsai, 2000).

In the analysis of the correlation between attachment style and compromising style, it was found that both of these variables had a significant positive relationship $(p=0.036)$ although the relationship between variables tended to be weak. This means that attachment style has an effect on adolescents in choosing a compromising style that guides adolescents to behave 'moderate' in finding solutions to the conflicts with others. This conflict resolution style refers to a solution that can satisfy adolescents and parties by making both parties equally beneficial or even equally not winning at all on conflicts.

Meanwhile the dominating style has a negative relationship that is not significant to the attachment style $(p=0.329)$. Characteristics of individual who form attachment styles are able to share their concern for themselves and others equally, are easy to cooperate with and are able to forge a mutually beneficial relationship. It is contrast to the characteristics of the individual with the dominating style, which tends to consider the needs or advantages of himself than others. They focus more on their needs that must be met in conflict rather than thinking of others. They are typically assertive and argumentative, making it difficult to reach mutual consent in conflict. (Friedman, Tidd, Currall, Tsai, 2000, Vokić \& Sontor, 2010).

Research shows that a high attachment style, referring to secure attachment, has a positive relationship with mental health. Otherwise, insecure attachment, refers to the low attachment style, has a negative relationship with mental health. A positive mental health will help the individual run a good psychological adjustment in his/her social environment, have effective emotional control and avoid individuals from maladaptive behavior (Polek, Van Oudenhoven \& Ten Berg, 2008; Bonab \& Koohsar, 2011). Mental health as a correlate of emotional intelligence correlates significantly with the effectiveness of controlling interpersonal conflict (Rostiana, 2004). The better a person's mental health, the higher the emotional intelligence he/she has, which significantly indicates that the individual has effective controls in solving the conflicts encountered. Therefore, adolescents with attachment style already have a good influence in emotions and are sensitive to other people's feelings, they are aware of the needs of others and are able to accept different perspectives, created a more effective conflict resolution process, including when adolescents choose to resolve conflicts by way of settlement that benefits both parties in conflict and even to give in to one party to the conflict.

Jamil states that communication and emotion are one of the factors that lead to conflict resolution (Puspitasari \& Nashori, 2008). Communication was able to bridge ideas and feelings from one party to another to find solutions to problems faced cooperatively, integrative and interactive decision making together. The better of communication skills he/she have, the better encouragement of all 
parties to communicate the needs and interests that need to be fulfilled in resolving the conflict. Emotion is the driving of any conflict. If one is able to think and behave calmly, rationally and objectively, it will be able to focus on how to resolve differences between the two parties involved in the conflict (Puspitasari \& Nashori, 2008). These factors are also raised in the attachment style formed by adolescents. Adolescents with a secure attachment style grow as individuals with better emotional intelligence than insecure attachment (Bonab \& Koohsar, 2011). Adolescents be able to controling their emotions better, not least when faced with conflict or other stressful situations, making it easier to express the point of view and the differences between themselves and the parties to the conflict in order to reach mutual agreement. They also growt the ability to establish cooperative relationships with others.

\section{REFERENCES}

Broadbear, B. C \& Broadbear, J. T. (2000). Development of conflict resolution skills in infancy and early childhood. The International Electronic Journal of Health Education, 3(4), 284-290.

Bartholomew, K. and Horowitz, L. M. (1991). Attachment styles among young adults: a test of a four-category model. Journal of Personality and Social Psychology, 61 (2), 226-244.

Bonab, B. G. \& Koohsar, A. A. H. (2011). Relation between emotional intelligence and attachment styles in delinquent adolescents. Procedia Social and Behavioral Sciences, 30, 963-967.

Collins, N. L. \& Feeney, B. C. (2004). Working models of attachment shape perceptions of social support: evidence from experimental and observational studies. Journal of Personality and Social Psychology, 87 (3), 363-383.

Dewi, A. A. A \& Valentina, T. D. (2013). Hubungan kelekatan orangtua-remaja dengan kemandirian pada remaja di smkn 1 denpasar. Jurnal Psikologi Udayana, 1 (1), 181-189.

Friedman, R.A., Tidd, S.T., Currall, S.C., Tsai, J.C. (2000). What goes around comes around: the impact of personal conflict style on work conflict and stress. International Journal of Conflict Management, 11(1), 32-55.

Hadipranoto, R. M. (2012). Peranan komunikasi dalam menyelesaikan konflik pada hubungan persahabatan siswa sma sedes sapientiae. Skripsi. Fakultas Psikologi, Universitas Katolik Soegijapranata, Semarang.

Havenga, W. (2008). Gender and age differences in conflict management within small business. $S A$ Journal of Human Resource Management, 6 (1), $22-28$.
Iriana, F. \& Ninawati. (2005). Gambaran kesejahteraan psikologis pada dewasa muda ditinjau dari pola attachment. Jurnal Psikologi, 3 (1).

Oredeina, A. O., \& Eigbe, M. (2014). Leadership negotiation skill as correlate of university conflict resolution in nigeria. Procedia - Social and Behavioral Sciences, 112, 1237 - 1245.

Polek, E., Van Oudenhoven, J.P. \& Ten Berge, J.M.F. (2008). Attachment styles and demographic factors as predictors of sociocultural and psychological adjustment of Eastern European emigrants in the Netherlands. International Journal of Psychology, 43: 919-928. DOI: 10.1080/00207590701484835. Diambil 18 Agustus 2015, dari http://www.ncbi.nlm.nih.gov/pubmed/2202279 9.

Polek, E., Van Oudenhoven, J. P., \& Ten Berge, J. M. F. (2011). Evidence for a 'migrant personality': Attachment styles of poles in poland and polish immigrants in the netherlands. Journal of Immigrant and Refugee Studies, 9 (4).

Prima, D. (2012, 30 September). Aksi tawuran pelajar dilandasi rasa solidaritas. Diambil 18 November 2014, dari http://www.inilah.com/.

Puspitasari, C. \& Nashori, F. (2008). Hubungan keterampilan komunikasi interpersonal dengan resolusi konflik pada remaja. Fakultas Psikologi dan Ilmu Sosial Budaya, Universitas Islam Indonesia, Yogyakarta.

Rahim, M. A., \& Magner, N. R. (1995). Confirmatory factor analysis of the styles of handling interpersonal conflict: first-order factor model and its invariance across groups. Journal of Applied Psychology, 80 (1), 122-132.

Rostiana. (2004). Hubungan antara kesehatan mental individu dengan efektivitas pengendalian konflik interpersonal pada karyawan. Skripsi. Fakultas Psikologi, Universitas Tarumanegara.

Santrock. J. W. (2002). Life-span development: Perkembangan masa hidup (Ed. kelima, jilid 1). Jakarta: Erlangga.

Van Oudenhoven, J.P., J. Hofstra, \& W. Bakker, 2003. Ontwikkeling en evaluatie van de hechtingstijlvragenlijst (hsl) [Development and evaluation of the attachment styles questionnaire]. Nederlands Tijdschrift voor de Psychologie, 58: 95-102.

Vokić, N.P., \& Sontor, S. (2010). The relationship between individual characteristics and conflict handling styles - the case of croatia. Problems and Perspectives in Management, 8 (3).

Zeinali, A., Sharifi, H., Enayati, M., Asgari, P., \& Pasha, G. (2011). The mediational pathway among parenting styles, attachment styles and selfregulation with addiction susceptibility of adolescents. Journal of Research in Medical Sciences: The Official Journal of Isfahan University of Medical Sciences, 16 (9), 11051121. 